\title{
Modelling and Simulation of Building Material Flows: Assessing the Potential for Concrete Recycling in the German Construction Sector
}

\author{
Clemens Mostert*(i), Christian Weber and Stefan Bringezu $\mathbb{1}$
}

Citation: Mostert, C.; Weber, C.; Bringezu, S. Modelling and

Simulation of Building Material

Flows: Assessing the Potential for Concrete Recycling in the German Construction Sector. Recycling 2022, 7,

13. https://doi.org/10.3390/ recycling7020013

Academic Editors: Abdol R. Chini, Tayyab Maqsood,

Salman Shooshtarian and

Domenico Asprone

Received: 21 December 2021

Accepted: 23 February 2022

Published: 1 March 2022

Publisher's Note: MDPI stays neutral with regard to jurisdictional claims in published maps and institutional affiliations.

Copyright: (C) 2022 by the authors. Licensee MDPI, Basel, Switzerland. This article is an open access article distributed under the terms and conditions of the Creative Commons Attribution (CC BY) license (https:// creativecommons.org/licenses/by/ $4.0 /)$.
Center for Environmental Systems Research (CESR), Faculty of Building and Environmental Engineering, University of Kassel, 34109 Kassel, Germany; c.weber90@gmx.de (C.W.); bringezu@uni-kassel.de (S.B.)

* Correspondence: mostert@uni-kassel.de

\begin{abstract}
The reuse and recycling of materials can make an important contribution to the conservation of natural resources in the sense of a circular economy. This applies in particular to high quality recycling, supporting the material use of waste and closing product cycles. The construction sector is the most important sector in terms of available volume of materials for recycling. However, the largest share of recycling $(\mathrm{RC})$ materials goes predominantly into road construction and underground engineering. This research developed a dynamic model and used a simulation tool to calculate future building material flows in the German construction sector of residential buildings to explore the medium- and long-term potential for RC concrete. The results show that, by increasing the RC rate of concrete to produce recycled aggregates for concrete (RAC) from currently $1.5 \%$ to $48 \%$, up to 179 million tons of sand and gravel could be saved until 2060. If the current maximum secondary input rate of RAC of $45 \%$ is increased to $70 \%$, the savings could rise over another 66 million tons. If a secondary input rate of $100 \%$ is applied, RAC could completely fulfill the demand for sand and gravel for new residential building in Germany from 2045 onwards. The approval of RC concrete for more concrete strength and exposure classes is required to avoid a surplus of RAC and a rapid exhaustion of landfill capacities in the future.
\end{abstract}

Keywords: concrete recycling; mineral construction waste; recycled aggregates; building material flows; residential buildings stock; urban mining; system dynamics

\section{Introduction}

\subsection{Resource Efficiency}

The extraction and use of primary raw materials is associated with considerable emissions to air, water and soil, and the related interventions are the major cause for environmental impacts, such as land use change, disturbance of regional water balance and biodiversity loss [1]. In the framework of the 'European Green Deal', the European Commission (EC) stressed the importance of the sustainable use of natural resources and long-term supply of raw materials for the prosperity of the global economy and society [2]. In this context, it is important to improve the collection and recycling processes of materials. The increased use of secondary raw materials, in the sense of a circular economy, can make an important contribution to limit the consumption of natural resources and to reduce environmental impacts compared to the use of primary raw materials [3].

The problems of high resource consumption and low resource efficiency, which are to be understood as part of the global sustainability debate, have increasingly become the focus of public attention in recent years. In politics, the topic has received attention in various forms. In 2015, the United Nations adopted 17 sustainable development goals (SDGs) in the form of the 2030 Agenda for Sustainable Development [4]. According to the International Resource Panel (IRP) of the United Nations, about 50\% of global greenhouse gas emissions can be traced back to the extraction and processing of fossil fuels, biomass, 
ores and minerals [5]. Based on the global climate crisis and the knowledge that natural resources are finite but of great importance for the global economy, it is clear that measures regarding effective and efficient use of raw materials are urgently needed [6]. With the help of the Resource Efficiency Program (ProgRess), Germany has been trying to use materials more efficiently and save primary raw materials in all industrial sectors since 2012. ProgRess II addresses fields of action such as sustainable construction, renovation and use of buildings, mineral material cycles and eco-design [7].

\subsection{Resource Consumption in the German Construction Sector}

The construction industry is the most resource-intensive sector [8]. It has the largest total stock of bound materials and is dominated by mineral materials. In Germany, the building materials concrete and brick account for the largest share [9]. The building stock and the dynamics of change, i.e., new construction and deconstruction measures, are decisive for the anticipation of building material flows. According to the German Federal Statistical Office (Destatis), the stock of residential buildings in Germany was approximately 19 million buildings or 41 million housing units (HU) in 2018 [10]. Germany has approximately 83 million inhabitants, but forecasts show that the population will decrease in the long term. It is assumed that the population will decrease to about 78 million inhabitants in 2060 [11]. A key challenge is to estimate what influence population development will have on the construction sector, especially on the housing market, in order to forecast resulting construction mass flows.

Approximately 206 million tons of construction and deconstruction waste are produced on average per year in Germany [12]. In 2016, almost 125 million tons of soil and stones accounted for the largest share with $58 \%$ followed by 58.5 million tons of deconstruction waste, consisting of concrete, brick, tile and ceramic with $27 \%$. The deconstruction waste represents a large recycling $(\mathrm{RC})$ potential. Through appropriate processing into RC building materials, these materials can contribute to resource conservation and resource efficiency.

Many materials, including concrete, metals and wood, are bound up in durable goods, such as buildings, bridges and other infrastructure. This anthropogenic stockpile of materials is referred to as the 'urban mine', and the approach of 'urban mining' generally refers to the use of secondary raw materials from the anthropogenic stockpile, which has mainly emerged in the last century [13]. The proportion of concrete in particular has risen sharply since the 1950s due to construction methods and the resulting increased use of the material [14]. The basic idea of urban mining is to estimate and quantify future building material flows, to process the material accordingly, and to reintegrate it as a secondary raw material into the cycle of materials [15]. On the one hand, urban mining contributes to the fact that finite primary raw materials do not have to be extracted from the environment. On the other hand, the approach reduces the amount of deconstruction waste and thus the storage in limited landfills. Urban mining will play a more important role in the future, because of rising raw material prices, a shortage of primary resources, increasing dependence on imports and growing environmental pollution [16].

In Germany, the average RC rate for mineral deconstruction waste is around 90\% [12]. In 2016, 72 million tons of RC materials were produced from the building sector. However, the largest share of RC materials is used as bulk material for road construction and underground engineering. The RC materials in road construction amount to about $53 \%$, a further $22 \%$ is processed in earthworks, $21 \%$ for the production of asphalt, and $4 \%$ is used elsewhere. In the construction of new buildings in Germany, RC materials are hardly used. These numbers show that RC materials are predominantly used in construction measures that are classified as low value, which is referred to as 'downcycling' [17].

For an increased reuse and recycling of building materials in the building construction sector, a selective dismantling, instead of the common demolition of old buildingshereinafter referred to as deconstruction-is required [18]. Although the EU waste directive prioritizes waste prevention and reuse [19], a high quality recycling and use of RC materials 
in new buildings with the closest possible material cycles should be strived for under aspects of resource conservation and resource efficiency. Deconstruction and sorting are central prerequisites to further process the deconstruction waste as recycled aggregates for concrete (RAC). The concrete produced partial or complete from RAC is referred to as RC concrete [20].

\subsection{Research Focus}

Even if there is a justified assumption that the use of RAC could contribute to a more resource efficient way of building construction, more reliable methodologies and simulation models are required to assess the production and use of RC concrete [21]. A promising approach for dynamic modelling and simulation of building mass flows is system dynamics (SD). In recent years, a number of studies have been published that have investigated the potential for recycling in the construction sector using SD mostly on the city level. One study developed an SD model to evaluate alternative type of recycling center under different policy and economy options, using the city of Chongqing as a case study [22]. Another recent study developed an SD model for the building stock of the city of Jinan to estimate the future environmental impacts [23].

This study focuses on the material-intensive building material flows in the German construction sector and examines the resource conservation potential that can be achieved through the use of $\mathrm{RC}$ materials in the construction of buildings. This resource conservation potential is the amount of natural primary raw materials, such as gravel and sand, which can be replaced by the use of RAC in concrete production. The central component of this study is the analysis of the material flows based on the change of the residential building stock. The year 2020 serves as the reference year. Non-residential buildings, i.e., production buildings, administrative buildings, hotels, etc., are not considered. The focus is on deconstruction waste with the European waste code number 17, which includes concrete, brick, metal, wood and gypsum [24]. Concrete and brick, which make up approx. 60-90\% of the demolition mass of a building, are therefore of great importance to achieve a high resource conservation potential [25]. The material or deconstruction mass flows of concrete and brick, which can be processed as RAC to substitute natural aggregates, such as sand and gravel, are analyzed. The construction waste generated due to new construction is not considered in this study.

With the help of dynamic modelling and simulation, future inflows and outflows of residential buildings in Germany are forecasted with assumed construction and deconstruction rates. Based on projected deconstruction activity, the masses of the building materials concrete and brick are determined, which have a high potential for RC and for saving natural aggregates in the construction sector. Finally, simulation experiments are executed to calculate building material quantities that allow conclusions to be drawn about potential resource conservation. The study provides answers to the following research questions:

(1) What is the potential for recycling 'from building construction to building construction', and what resource conservation potential results from this?

(2) Can the demand for RAC for the construction of new residential buildings be met in the future?

(3) How much natural raw materials can be saved by using more $\mathrm{RC}$ concrete in the future?

The analysis includes quantitative projections and the simulation of different scenarios to classify the anthropogenic material stock and the building material flows of the residential building sector in Germany in terms of size. In addition, the work is intended to draw attention to the relevance of a sustainably oriented circular economy in the construction sector under the limited availability of primary raw materials

\section{Methods and Data}

\subsection{Modelling with System Dynamics}

The system dynamics (SD) methodology pursues the goal of modelling and simulating the behavior of an existing real system as accurately as possible [26]. In general, real systems 
are very complex and consist of many relationships and interrelationships between the different system components that change over time. Therefore, the modelling can only cover a partial section of the real system to be examined. In order to better understand the dynamic development and change in the system parameters, simulation experiments are carried out and results are analyzed.

Three criteria characterize a system. It fulfils a certain function, consists of several elements that are interrelated, and is not divisible [27]. Within a system, there are links and feedbacks between the system elements. A mutual influence of two elements is called feedback, which either strengthens or dampens the effect between the elements. A system is separated from its system environment by a system boundary. Several factors have an influence on the system. External impacts have an effect on the system behavior, but in general, the system also influences its system environment. In summary, it can be stated that the system dynamics results from system influences from outside the system and from feedbacks between the elements inside the system.

Modeling and simulation require a close observation and analysis of the system to be modelled in order to achieve a realistic representation [28]. This includes researching relevant data and information of the system under study to understand its structure and dynamics. The development of a model requires the following steps [27]. As a first step, the model purpose and the system boundary must be defined. The model purpose describes the goal of the model and what question it is supposed to answer. The system boundary defines which elements are considered part of the system and which are considered to belong to the system environment. In the next step, all components of the system have to be determined and named. With the help of the defined system boundary, relevant elements can be divided into system endogenous and exogenous. This is followed by the creation of the word model. The word model is a written description of all relationships between the system-relevant elements. The last phase before designing the SD model involves the creation of a causal-loop diagram (CLD). The impact links that have already been documented in the word model are thereby transferred into a CLD. The diagram makes the structure of the system recognizable and represents a first quantitative model. Through the representation in the CLD, connections and links between the system elements can be recognized and thus a better understanding of the system can be achieved. At the same time, the CLD forms the basis for the SD model. In this study, the SD software 'Powersim Studio Academic 2005' was used for modelling and simulation.

\subsection{Model Aim and Structure}

The aim of this model is to determine the resource conservation potential based on the total amount of primary raw material that can be saved by processing material from building deconstruction to be used as RAC for concrete production in Germany. The model takes into account the current technical and legal framework conditions. It should be able to change relevant parameters and to analyze and compare the results. Figure 1 illustrates the structure of the SD model.

The model is based on the following impact links: A higher demand for aggregates for concrete increases the use of sand and gravel and consequently accelerates the depletion of natural primary materials. A reduced 'stock index of sand and gravel' increases the prices of natural raw materials and therefore leads to higher RC rates of deconstruction waste, referred to as 'concrete recycling rate' in the model. The increased use of RAC and RC concrete will consequently reduce the use of 'sand and gravel'. Two material flows are essentially relevant for this. The construction activities drive the 'demand for aggregates for concrete'. The deconstruction activities determine the 'deconstruction mass for recycling' and consequently the available amount of RAC based on the 'concrete recycling rate'. 'Construction' and 'deconstruction' also determine the development of the 'housing unit stock' and consequently the 'net stock change'. The focus of the study is on the German housing sector with the building materials concrete and brick, which can be further processed as RAC. Under the assumed construction activities, the model 
shows which quantities of RAC can be obtained from the deconstruction of old buildings

to produce $\mathrm{RC}$ concrete for the construction of new buildings.

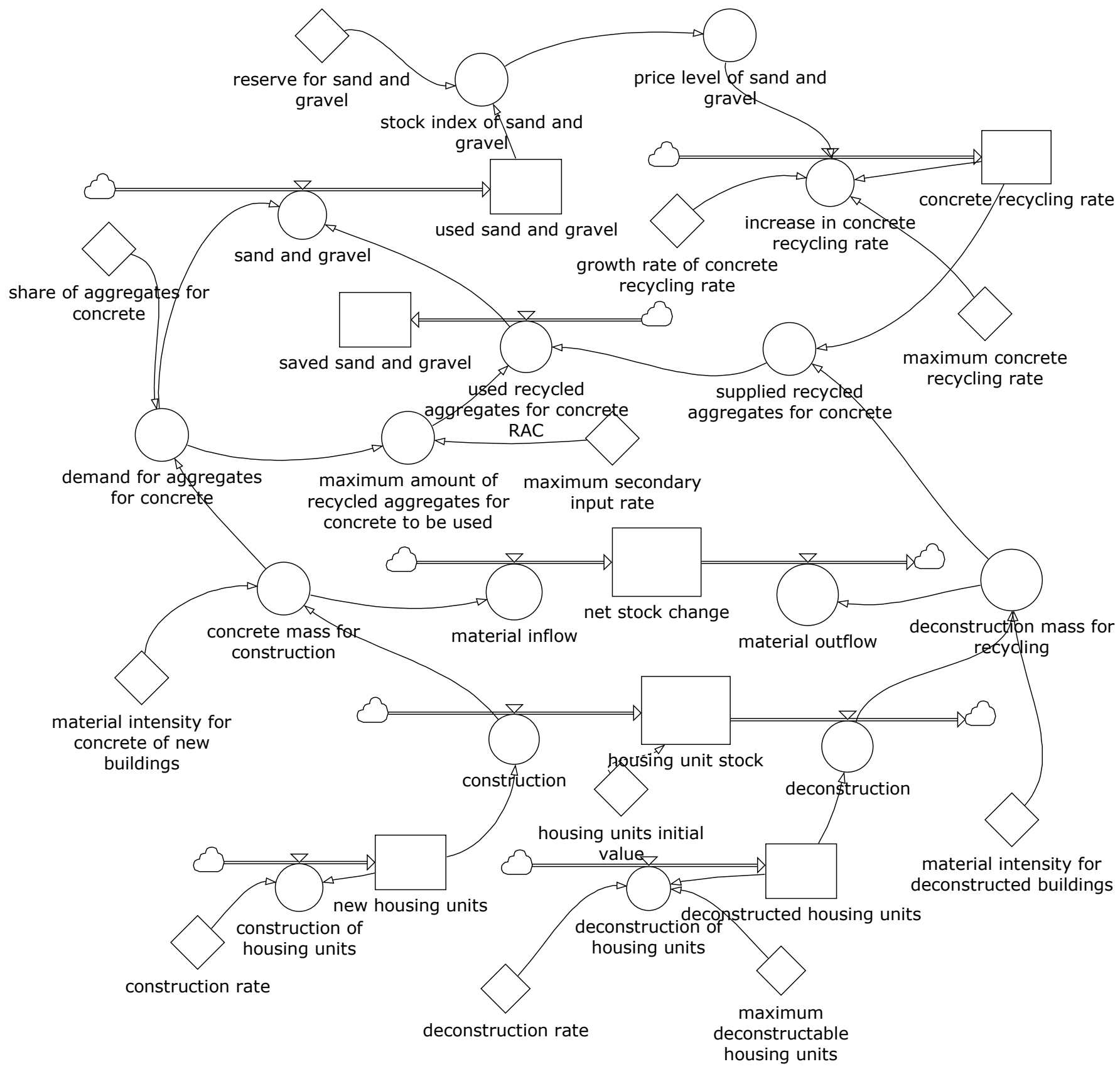

Figure 1. System dynamics (SD) model for the calculation of the resource conservation potential, calculated as the amount of primary raw material that could be saved by producing recycled aggregates for concrete (RAC) for use of recycling (RC) concrete in the German residential buildings construction sector.

The basis of the model is the development of the residential building stock calculated in HU. The 'construction' and 'deconstruction' lead to the changes in the 'housing unit stock', starting with the baseline 'housing units initial value'. The 'construction' and 'deconstruction' are driven by the 'construction rate' and 'deconstruction rate', which are derived from the projected demographic development. In order to transform the HU into building masses, material intensities are calculated. For calculating the available 'deconstruction mass for recycling' the 'material intensity for concrete and bricks of old 
buildings' is used. The 'material intensity for concrete of new buildings' is used to calculate the required 'concrete mass for construction'.

Based on the actual 'concrete recycling rate' the amount of 'supplied recycled aggregates for concrete' can be determined, which is driven by the 'deconstruction mass for recycling'. The 'concrete mass for construction' determines the 'demand for aggregates for concrete'. The demand is driving the use of 'sand and gravel' and the 'maximum amount of recycled aggregates to be used', which is limited by the 'maximum secondary input rate' according to the current legal standards and regulations. Based on the amount of 'used recycled aggregates for concrete' the amount of 'saved sand and gravel' can be calculated to answer the initial research questions.

The total amount of 'used sand and gravel' reduces the 'stock index of sand and gravel', based on the defined 'reserve for sand and gravel'. The decrease in the 'stock index of sand and gravel' leads to an increase in the 'price level of sand and gravel' and consequently to an 'increase in concrete recycling rate'. The increase is limited by a 'maximum concrete recycling rate', which is determined by the collection and processing losses.

\subsection{Data and Assumptions}

The modelling and calculation are based on different assumptions and data sources. In general, it is assumed that, in the long term, deconstruction measures in Germany will increase and new construction activities will decrease. The dynamic development of construction activity is complex and depends on several factors, such as housing demand, number of households, migration, economic conditions and the life cycle of buildings. Most studies use population projections to explain housing stock development and thus new construction and deconstruction activity [29].

The German population was 83.2 million in 2020. According to population projection, it is expected that the population will continue to increase until 2024. From 2025 onwards, the population figures will fall continuously. In 2060, approx. 78.2 million inhabitants are expected. This data is based on the population projection variant, which assumes a moderate birth rate, life expectancy and net migration [11]. It is assumed that population development significantly drives the change in the 'housing units stock' and leads to a decrease in new construction activities in the future as population figures fall.

In 2020, the construction of residential buildings was around 251,000 HU per year and the deconstruction around 21,000 HU per year [30]. The calculated rates for new construction and deconstruction of residential buildings are based on the forecasts for future construction activities in Germany [25]. According to this study, in 2050 the construction of new residential buildings is expected to be around 106,000 HU per year and the deconstruction around $281,000 \mathrm{HU}$ per year. This scenario is reproduced by adjusting the rates for construction and deconstruction. Based on this data, the model assumes a decline in the construction rate of $2.8 \%$ per year and an increase in the deconstruction rate of $17.7 \%$ per year. In order to answer the research questions, the newly build and deconstructed $\mathrm{HU}$ are converted into material flows using material intensities. The newly build $\mathrm{HU}$ are multiplied by the material intensity for concrete in order to determine the demand for building materials. The deconstructed HU are multiplied with the material intensity for concrete and brick to determine the deconstruction masses that are available for processing into RAC which represent the potential secondary raw material supply for concrete production. The following material intensities are used for modelling: 152 tons of concrete and bricks per HU for deconstruction and 146 tons of concrete per HU for new construction [25].

The initial value of the 'concrete recycling rate' (year 2020) for the production of $\mathrm{RAC}$ is $1.5 \%$. The 'growth rate of the concrete recycling rate', that causes the RC rate to increase in the future, is $1.5 \%$ per year. These values are recalculated from the historic value of $0.4 \%$ in 2010 and the expected value of $6 \%$ in 2030 [31]. The 'maximum concrete recycling rate' is considerably influenced by two essential factors: (1) collection losses and (2) processing losses. Since the fractions concrete and brick do not occur individually in 
the deconstruction mass, but mixed within the total fraction, losses must be considered in the building material output for the production of RAC. The use of RAC is subject to special requirements regarding their properties, such as specific gravity, absorption and the total amount contribute to the strength and durability of concrete [32]. Despite selective deconstruction and maximum sorting of waste, there are around $20 \%$ losses in the deconstruction material output for use as aggregates, depending on the applied technology [25]. For the construction of new residential buildings in Germany, the guideline of the 'Deutsche Ausschuss für Stahlbeton' (DAfStb) is of particular importance [33]. As the DAfStb do not allow the use of aggregates smaller than $2 \mathrm{~mm}$ discharge losses can be up to $40 \%$. Taken together, the collection and discharge losses result in a 'maximum concrete recycling rate' of $48 \%$ [25]. The DAfStb also limits the use of RAC by specifying a maximum RAC share of the total aggregate volume in concrete. The secondary input rate or substitution rate is a parameter that defines the ratio of secondary material to total material input. The ratio indicates which quantities of primary materials are replaced by $\mathrm{RC}$ materials and thus measures the functionality of the circular economy. The 'maximum secondary input rate' of RAC is currently limited to $45 \%$ in Germany depending on the type of concrete.

A further model assumption is the total amount of natural material resources that is available for the construction of new residential buildings. The 'sand and gravel reserve' is set at 730 billion tons, which is 20 times the current gravel and sand demand of this sector in Germany. Finally, only completely newly build and demolished buildings with constant material intensities are considered in the calculation. Building material masses from construction activities in the existing stock, such as refurbishments, conversions, extensions or partial demolitions, are not taken into account. Table 1 summarizes the major parameter, data and data sources used in the modelling and calculation.

Table 1. Parameter, data and data source used for the modelling and calculation.

\begin{tabular}{ccc}
\hline Parameter & Data & Source \\
\hline Housing stock (initial value) & $41,000,000$ housing units [HU] & {$[10,30]$} \\
Construction (initial value) & 251,000 housing units [HU/yr] & {$[10,30]$} \\
Deconstruction (initial value) & 21,000 housing units [HU/yr] & {$[10,30]$} \\
Concrete recycling rate (initial value) & 1.5 percent [\%] & Own calculation [31] \\
Change in concrete recycling rate & +1.5 percent per year [\%/yr] & Own calculation [31] \\
Change in construction rate & -2.8 percent per year [\%/yr] & Own calculation [25] \\
Change in deconstruction rate & +17.7 percent per year [\%/yr] & Own calculation [25] \\
Material intensity of concrete for new buildings & 146 tons per housing unit [t/HU] & Own calculation [25] \\
Material intensity of concrete and bricks from old buildings & 152 tons per housing unit [t/HU] & Own calculation [25] \\
Maximum secondary input rate & 45 percent [\%] & [33] \\
Maximum concrete recycling rate & [25] percent [\%] & Own calculation \\
Reserve for sand and gravel & 730 million tons [Mt] &
\end{tabular}

\subsection{Scenarios}

To better estimate the resource conservation potential that can be achieved by processing deconstruction material into RAC, three different scenarios are analyzed:

1. Recycling (RC) scenario;

2. Secondary Input (SI) scenario;

3. Resource Saving (RS) scenario.

The activities in the sector, which are determined by the new construction and deconstruction rate and the resulting inflows and outflows of residential buildings, are equal in all three scenarios. In the SI and RS scenarios, the parameters 'maximum concrete recycling rate', 'maximum secondary input rate' and 'reserve for sand and gravel' are changed compared to the RS scenario, in order to gain better insights into the effects of these model parameters on the simulation results. In the RC scenario, construction activities develop according to the underlying forecasts. The 'concrete recycling rate' increases from $1.5 \%$ to 
$48 \%$, but the other main input parameters remain unchanged in the simulation period. In the SI scenario, the 'maximum secondary input rate' increases from $45 \%$ to $70 \%$, which is in line with pilot projects already carried out in Germany. In addition, it is assumed that due to a change in the DAfStb the use of aggregates smaller than $2 \mathrm{~mm}$ discharge is allowed as RAC resulting in a 'maximum concrete recycling rate' of $54 \%$. In the RS scenario, additional measures and the resulting change in the resource savings potential are analyzed. Based on the experience, that RC concrete can be produced entirely from RAC the 'maximum secondary input rate' is set to $100 \%$. The 'maximum concrete recycling rate' remains at $54 \%$. It is assumed that the maximum 'reserve for sand and gravel' is $530 \mathrm{Mt}$, i.e. $200 \mathrm{Mt}$ lower compared to the other two scenarios, as a high RC level is reached and primary raw material use is reduced in the context of the circular economy. Table 2 gives an overview about the three analyzed scenarios and the relevant parameters.

Table 2. Overview of the three scenarios and related parameters.

\begin{tabular}{ccc}
\hline Scenario & Parameters & Values \\
\hline \multirow{3}{*}{ Recycling (RC) } & maximum concrete recycling rate & $48 \%$ \\
& maximum secondary input rate & $45 \%$ \\
& reserve for sand and gravel & $730 \mathrm{Mt}$ \\
\hline \multirow{2}{*}{ Secondary Input (SI) } & maximum concrete recycling rate & $54 \%$ \\
& maximum secondary input rate & $70 \%$ \\
& reserve for sand and gravel & $730 \mathrm{Mt}$ \\
\hline \multirow{2}{*}{ Resource Saving (RS) } & maximum concrete recycling rate & $54 \%$ \\
& maximum secondary input rate & $100 \%$ \\
& reserve for sand and gravel & $530 \mathrm{Mt}$ \\
\hline
\end{tabular}

\section{Results}

\subsection{Key Drivers}

The model behavior is essentially driven by three exogenous parameters. The parameters (1) 'deconstruction mass for recycling', (2) 'demand for aggregates for concrete' and (3) 'reserve for sand and gravel' play a central role in the consideration of the real system. The resulting 'deconstruction mass for recycling' and the 'concrete mass for construction' can be determined via the activities in the building sector, i.e., deconstruction and construction of HU. Figure 2 shows the simulated (de)construction activities in the German construction sector for residential buildings and the resulting material flows and net stock changes for the period from 2020 to 2060.

The curve of 'construction' shows a continuous decline, and the 'deconstruction' shows a logistic growth that is characterized by an S-shaped curve, as a certain limit is reached over time and saturation occurs. Analogously, the 'concrete mass for construction' shows a continuous decline. The required concrete mass starts at the highest level of $36.71 \mathrm{Mt} / \mathrm{yr}$ in 2020. From 2020 onwards, it decreases to $11.88 \mathrm{Mt} / \mathrm{yr}$ in 2060. The curve of 'deconstruction mass for recycling' shows an exponential growth in the beginning and a limited growth at the end of the simulation period. In 2020, the deconstruction mass amounts to $3.2 \mathrm{Mt} / \mathrm{yr}$ and in 2060 to $45.2 \mathrm{Mt} / \mathrm{yr}$. As a result, the 'net stock change' increases until 2036 and then decreases as the deconstruction mass exceeds the required concrete mass.

\subsection{Recycled Aggregates for Concrete}

Figure 3 shows the simulated amount of used 'recycled aggregates for concrete' in the different scenarios used for the construction of residential buildings in Germany in relation to the demand of 'aggregates for concrete' in mega tons per year from 2020 to 2060. 

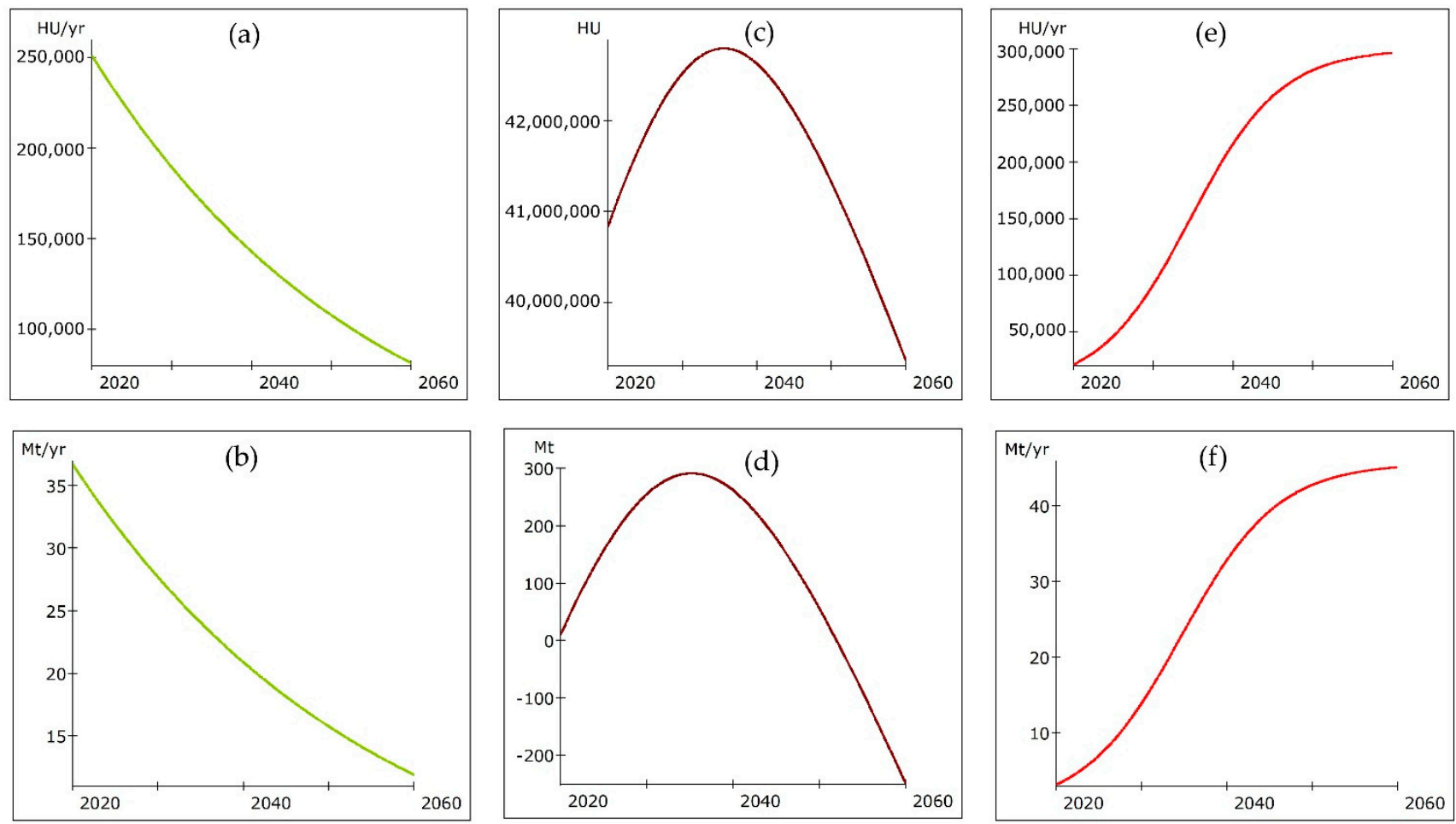

Figure 2. Activities in the German residential building sector from 2020 to 2060 shown by the evolution (a) of the 'construction' measured in housing units per year (HU/yr); (b) of the related 'concrete mass for construction' measured in mega tons per year (Mt/yr); (c) of the housing unit stock measured in housing units (HU); (d) of the 'net stock change' of construction material measured in mega tons (Mt); (e) of the 'deconstruction' measured in housing units per year (HU/yr); (f) of the related 'deconstruction mass' measured in mega tons per year (Mt/yr).

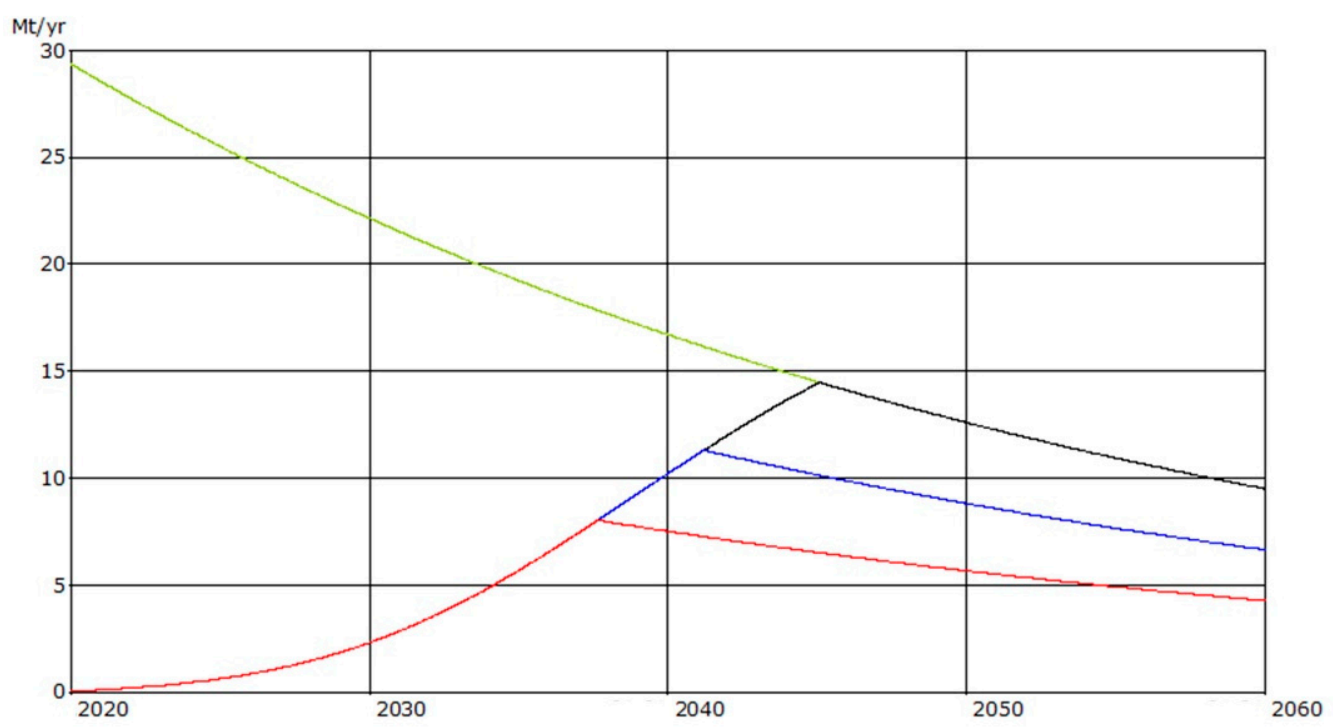

Figure 3. Evolution of the 'demand of aggregates for concrete' (green) in the German construction sector of residential buildings compared with the 'used recycled aggregates for concrete' in the different scenarios from 2020 to 2060, measured in mega tons per year (Mt/yr): Recycling (RC) scenario (red), Secondary Input (SI) scenario (blue), Resource Saving (RS) scenario (black). 
Due to the falling construction rate of new HU, the 'demand for aggregates for concrete' is also decreasing. In 2020, it is $29.37 \mathrm{Mt} / \mathrm{yr}$ and goes down to $9.50 \mathrm{Mt} / \mathrm{yr}$ in 2060 . In all three scenarios, the evolution of the 'used recycled aggregates for concrete' starts at a very low level from $0.32 \mathrm{Mt} / \mathrm{yr}$ in 2020 and increases to $7.95 \mathrm{Mt} / \mathrm{yr}$ by 2038. In the RC scenario, 2038 is the peak in the evolution of the 'used recycled aggregates for concrete' and it then steadily declines to $4.28 \mathrm{Mt} / \mathrm{yr}$ by 2060 . In the SI scenario, the evolution of the 'used recycled aggregates for concrete' reaches the peak in 2041 with $11.05 \mathrm{Mt} / \mathrm{yr}$ and then steadily declines to $6.65 \mathrm{Mt} / \mathrm{yr}$ by 2060. Only in the RS scenario, the 'used recycled aggregates for concrete' are able to completely fulfill the 'demand for aggregates for concrete'. The evolution of the 'used recycled aggregates for concrete' peaks in 2045 with $14.44 \mathrm{Mt} / \mathrm{yr}$ and then steadily declines to $9.50 \mathrm{Mt} / \mathrm{yr}$ by 2060 .

\subsection{Savings in Sand and Gravel}

Figure 4 shows the evolution of the cumulative quantities of 'saved sand and gravel' over the simulation period from 2020 to 2060 for the different scenarios.

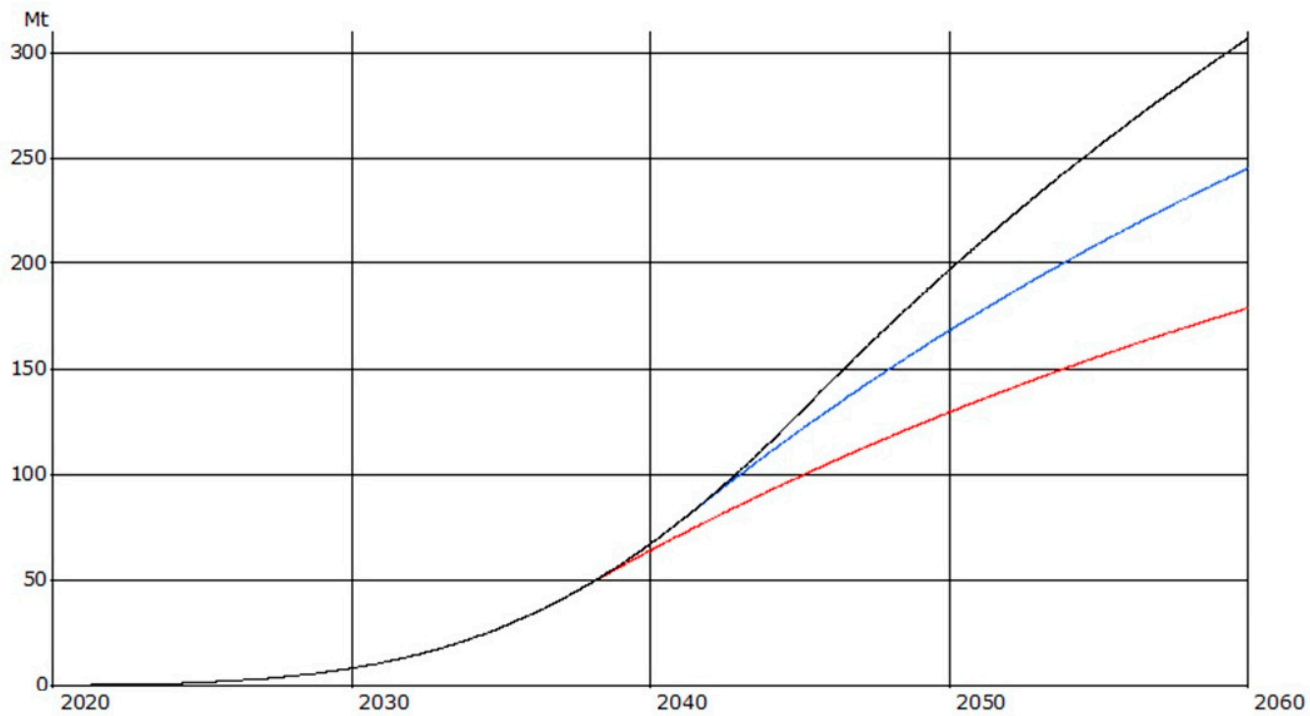

Figure 4. Evolution of 'saved sand and gravel' in the different scenarios from 2020 to 2060, measured in mega tons (Mt): Recycling (RC) scenario (red), Secondary Input (SI) scenario (blue), Resource Saving (RS) scenario (black).

By increasing the RC rate of concrete from the current $1.5 \%$ to $48 \%$, a saving of $179 \mathrm{Mt}$ of primary raw materials, such as sand and gravel, could be achieved until 2060 (RC scenario). If a secondary input rate of $70 \%$ is applied, the savings would increase by $66 \mathrm{Mt}$ to $245 \mathrm{Mt}$ (SI scenario). A secondary input rate of $100 \%$ would further increase the savings to 307 Mt until 2060 (RS scenario).

\subsection{Future Oversupply of Recycled Aggregates}

Figure 5 shows the evolution of the cumulative quantities of 'unused recycled aggregates for concrete' over the simulation period from 2020 to 2060 for the different scenarios.

In all three scenarios, there is an oversupply of 'unused recycled aggregates for concrete'. In the RC scenario, a quantity of 'unused recycled aggregates for concrete' is created as early as 2038, which increases to $260 \mathrm{Mt}$ until 2060. In the SI scenario, the oversupply is $150 \mathrm{Mt}$. In the RS scenario, an oversupply occurs from 2046 onward and sums up to 90 Mt until 2060. 


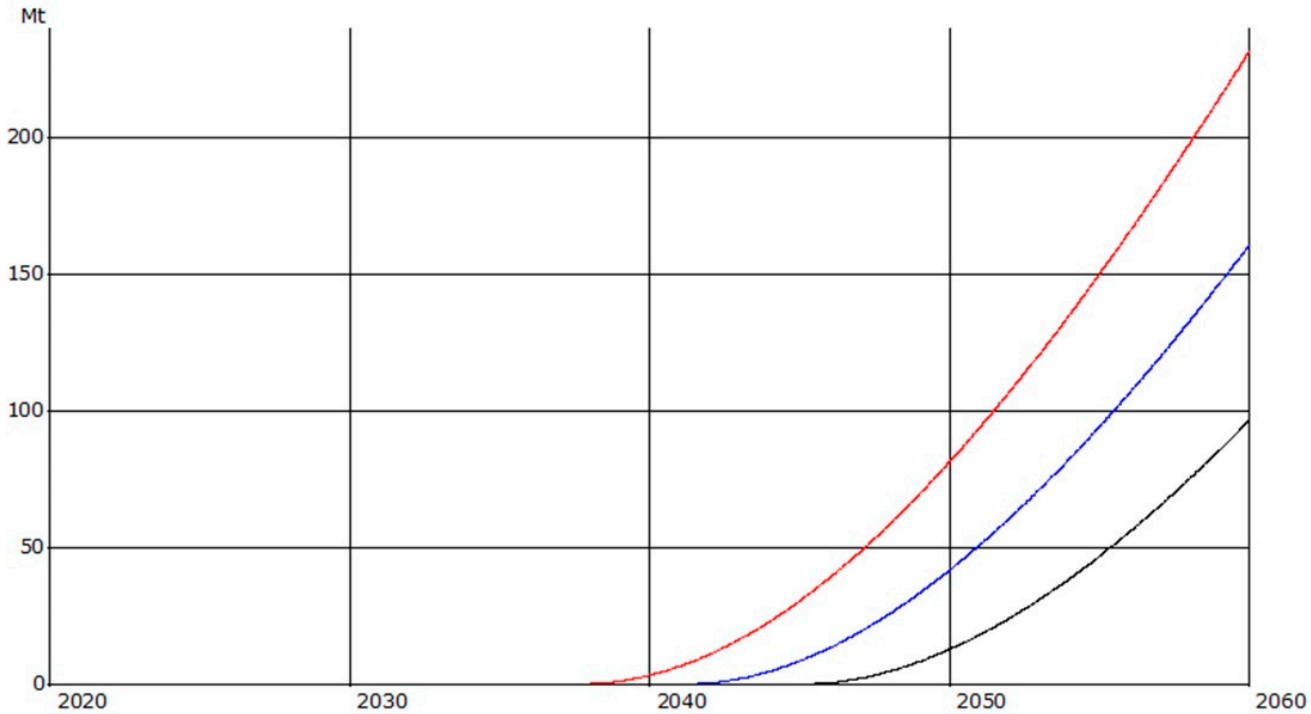

Figure 5. Evolution of the 'unused recycled aggregates for concrete' in the different scenarios from 2020 to 2060, measured in mega tons (Mt): Recycling (RC) scenario (red), Secondary Input (SI) scenario (blue), Resource Saving (RS) scenario (black).

\section{Discussion and Conclusions}

At present, RAC play only a minor role in the construction of residential buildings in Germany. It remains an open question whether the importance of alternative building materials will increase in the future, and whether RC concrete can be further established on the market for construction materials. As the properties of RC concrete are not always comparable to those of concrete made from natural aggregates-this can be a major obstacle to its practical application [34]. Therefore, a number of efforts are being made to avoid the inferior performance of RC concrete. For example, a recently developed technology uses waste rubber for RAC production and a new casting approach to increase the durability and compressive strength of RC concrete [35]. Other approaches have used wastewater from the concrete plant in combination with a carbonation method in order to enhance the quality of RAC [36].

In the future, a decline of the population, a saturation of the building stock and a migration of people from rural areas to cities is expected in Germany; therefore, larger amounts of wastes from the deconstruction of residential buildings will be available. These deconstruction masses have a great potential to save natural building materials such as sand and gravel by processing them into RAC for RC concrete production. In order to calculate the building material flows in the German residential building sector and to determine resource conservation potential of RC concrete, simulation experiments were carried out for the period over the next 40 years. The simulation was done with a dynamic model using the SD approach.

The simulated (de)construction activities in the residential building sector are quantitatively in line with other projections on the development of construction activity in Germany [37]. The results of the scenario analysis show that up to $300 \mathrm{Mt}$ of primary raw material could be saved from the deconstruction waste of residential building, which is about 10 times the current demand of sand and gravel. The amount of the savings that can be achieved depends mainly on the parameters 'concrete recycling rate', 'maximum secondary input rate' and the maximum amount usable sand and gravel defined as 'reserve for sand and gravel'.

All three scenarios are based on the assumption that demand for 'aggregates for concrete' could be always met by primary and secondary material. This assumption was made in order to show how the resource conservation potential, expressed in 'saved sand and gravel', can develop under different conditions, in particular through the increased 
use of RAC. The secondary material is used according to the current legal standards for manufacturing RC concrete in Germany and calculated as 'used recycled aggregates for concrete'. Therefore, the RC material input quantities correspond to the maximum legally permitted input quantities of RAC in all scenarios. Because of the projected increase in deconstruction waste and the increase in the recycling rate, the simulation results show a sharp increase in the use of secondary material in all scenarios. The use starts from the very low level of $0.32 \mathrm{Mt} / \mathrm{yr}$ in 2020 to a maximum of $7.95 \mathrm{Mt} / \mathrm{yr}$ in 2038 for the RC scenario and to a maximum of $11.14 \mathrm{Mt} / \mathrm{yr}$ in 2041 in the SI scenario. In the RS scenario, the maximum amount of used RAC is $14.44 \mathrm{Mt} / \mathrm{yr}$ in 2045, which corresponds to a 45 -fold increase over 25 years.

The results show that, with a higher amount of deconstruction mass available for the production of RAC, more RC building materials can be produced, but the total amount of available RAC depends very much on the recycling efforts. In the simulation experiments, it could be determined that an increase in the 'concrete recycling rate' from the initial value of $1.5 \%$ up to $48 \%$ has the highest impact on the resource conservation potential.

The increase in the 'concrete recycling rate' is mainly influenced by the 'price level of sand and gravel', which depends on the remaining raw material reserve. The total amount of 'used sand and gravel' for the construction of residential housing sector comprises between 400 and $525 \mathrm{Mt}$ over the simulation period. This sector therefore represents a comparatively small savings potential, as currently about $250 \mathrm{Mt}$ of sand and gravel are produced in Germany annually. However, while sand is available in sufficient quantities almost everywhere in Germany, the supply situation for gravel is much more strained, since first-supply bottlenecks have already occurred in recent years [38].

An increase in the 'reserve for sand and gravel' would lead to a slower increase in the price level, which consequently would slow down recycling efforts, and vice versa. In the RC scenario, the price level shows a continuous increase up to 3.4 in 2060. In the RS scenario, the prices level reaches 3.2 in 2042 and remains constant until 2060. The SI scenario shows the best economic performance with a continuous increase up to 2.5 in 2060 .

The current German legislation limits the 'maximum secondary input rate' to $45 \%$ depending on the type of concrete. The simulation results show that an increase in the secondary input rate up to $100 \%$ is required to achieve the full saving potential. Against this background, it could make sense to prescribe a minimum proportion of RAC that has to be applied in concrete production, which may continuously be increased over time. The technical feasibility has already been demonstrated in various pilot projects [39]. In this way, it could be legally stipulated that a defined quantity of RAC must be used for concrete in building construction in order to conserve natural resources. If the RC concrete does not show any disadvantageous properties compared to conventional concrete, even a $100 \%$ share of RAC can be applied.

The simulation results show that within the next 25 years, the amount of 'supplied recycled aggregates for concrete' could even exceed the 'used recycled aggregates for concrete'. Currently, the application of RAC is limited according to the compressive strength and exposure class of concrete in Germany [33]. Due to the comparably low secondary input rate and limited application of RC concrete, the potential of alternative building materials cannot be fully exploited. Therefore, an adjustment of the current legal framework should be considered so that the amount of RC building materials actually used increases and the maximum resource savings potential can be achieved.

By considering the enormous future increase in mineral deconstruction masses, it can be expected that large volumes of RAC cannot be returned to the cycle of building materials in the long term. The simulation results show that, even with a secondary input rate of $100 \%$ for RAC, a surplus of material occurs that cannot be used in building construction. This finding is confirmed by other studies, mainly due to the expected decline of new construction activities in the future [37].

One possible approach would be to reuse the surplus RAC from building construction, for example, as bulk material in road construction. However, in the future, it is assumed 
that there will also be less new activity in road construction, so that the capacities for the additional input of RC materials from building deconstruction will be limited. The road construction sector plans to reuse the deconstruction masses resulting from rehabilitation measures as secondary materials, which means that the demand might be largely covered in the future, and there would be no additional demand from building construction [40].

In view of the lack of recycling options, it should also be noted that the disposal of deconstruction waste is already becoming increasingly difficult in Germany. The capacities for mineral waste in landfills are decreasing significantly. As of 2016, the available landfills may still have a capacity in a range of about 20 years [41]. This leads to scarce landfill capacities and causes higher disposal fees. In addition, transportation costs increase because longer transport distances have to be covered due to the limited landfill options. One possibility to meet these challenges is increasing the application options for RC concrete, e.g., the approval of RAC in more concrete strength and exposure classes. This approval would mean that the surplus RAC in building construction could be reduced, and new recycling options can be used, which would subsequently increase the potential for resource conservation.

The results of the analysis can be used as initial indications for further research in the field of resource conservation in the building sector. In the view of the future oversupply of RAC in the residential building sector, it is clear that further research is needed to investigate new recycling options and consider the regional aspects of building material stocks and flows [42]. Additionally, the relationship between the 'price level of sand and gravel' and the 'concrete recycling rate' should be studied more intensively in the future. In terms of resource conservation and efficiency, the production of high-quality RAC and the application of high secondary input rates should be achieved in order to increase the substitution of primary raw materials, achieve higher savings of natural resources, and secure the supply of important building materials.

Author Contributions: C.M., conceptualization, methodology, modelling and simulation, validation, visualization, writing - review and editing; C.W., investigation, data, modelling and simulation, writing —original draft preparation; S.B., conceptualization, supervision, writing—review and editing. All authors have read and agreed to the published version of the manuscript.

Funding: This research received no external funding.

Institutional Review Board Statement: Not applicable.

Conflicts of Interest: The authors declare no conflict of interest.

\section{References}

1. OECD. Global Material Resources Outlook to 2060: Economic Drivers and Environmental Consequences; OECD Publishing: Paris, France, 2019. [CrossRef]

2. EC. Communication from the Commission to the European Parliament, the European Council, the Council, the European Economic and Social Committee and the Committee of the Regions; The European Green Deal. 2019. Available online: https: / / eur-lex.europa.eu/resource.html?uri=cellar:b828d165-1c22-11ea-8c1f-01aa75ed71a1.0002.02/DOC_1\&format=PDF (accessed on 21 February 2022).

3. Abad-Segura, E.; de la Fuente, A.B.; González-Zamar, M.-D.; Belmonte-Ureña, L.J. Effects of Circular Economy Policies on the Environment and Sustainable Growth: Worldwide Research. Sustainability 2020, 12, 5792. [CrossRef]

4. UN General Assembly. Transforming Our World: The 2030 Agenda for Sustainable Development. A/RES/70/1. 21 October 2015. Available online: https://www.refworld.org/docid/57b6e3e44.html (accessed on 21 February 2022).

5. Oberle, B.; Bringezu, S.; Hatfeld-Dodds, S.; Hellweg, S.; Schandl, H.; Clement, J.; Cabernard, L.; Che, N.; Chen, D.; Droz-Georget, H.; et al. Global Resources Outlook 2019: Natural Resources for the Future We Want; A Report of the International Resource Panel; United Nations Environment Programme: Nairobi, Kenya, 2019. Available online: https:/ /www.resourcepanel.org/reports/ global-resources-outlook (accessed on 21 February 2022).

6. Taušová, M.; Čulková, K.; Tauš, P.; Domaracká, L.; Seňová, A. Evaluation of the Effective Material Use from the View of EU Environmental Policy Goals. Energies 2021, 14, 4759. [CrossRef]

7. Federal Ministry for the Environment, Nature Conservation, Building and Nuclear Safety. German Resource Efficiency Programme II, Programme for the Sustainable Use and Conservation of Natural Resources. 2016. Available online: https:/ /www.bmu.de/ fileadmin/Daten_BMU/Pools/Broschueren/german_resource_efficiency_programme_ii_bf.pdf (accessed on 21 February 2022). 
8. Arora, M.; Raspall, F.; Cheah, L.; Silva, A. Buildings and the circular economy: Estimating urban mining, recovery and reuse potential of building components. Resour. Conserv. Recycl. 2020, 154, 104581. [CrossRef]

9. Schiller, G.; Müller, F.; Ortlepp, R. Mapping the anthropogenic stock in Germany: Metabolic evidence for a circular economy. Resour. Conserv. Recycl. 2017, 123, 93-107. [CrossRef]

10. Destatis. Bautätigkeit und Wohnungen [Construction Activity and Housing]. Fachserie 5, Reihe 3. 2019. Available online: https://www.destatis.de/DE/Themen/Gesellschaft-Umwelt/Wohnen/Publikationen/Downloads-Wohnen/bestandwohnungen-2050300187004.pdf?_blob=publicationFile (accessed on 21 February 2022).

11. Destatis. Bevölkerung im Wandel. Annahmen und Ergebnisse der 14. koordninierten Bevölkerungsvorausberechnung [Population in Transition. Assumptions and Results of the 14th Coordinated Population Projection]. 2019. Available online: https://www. destatis.de/DE/Presse/Pressekonferenzen/2019/Bevoelkerung/pressebroschuere-bevoelkerung.pdf?_blob=publicationFile (accessed on 21 February 2022).

12. BBS. Mineralische Bauabfälle Monitoring 2016. Bericht zum Aufkommen und zum Verbleib mineralischer Bauabfälle im Jahr 2016 [Mineral Construction Waste Monitoring 2016. Report on the Generation and Fate of Mineral Construction Waste in 2016]. 2018. Available online: https://www.baustoffindustrie.de/fileadmin/user_upload/bbs/Dateien/Downloadarchiv/Umwelt/ 11_KWB_Monitoring-Bericht.pdf (accessed on 21 February 2022).

13. Lanau, M.; Liu, G.; Kral, U.; Wiedenhofer, D.; Keijzer, E.; Yu, C.; Ehlert, C. Taking Stock of Built Environment Stock Studies: Progress and Prospects. Environ. Sci. Technol. 2019, 53, 8499-8515. [CrossRef]

14. Gagg, C.R. Cement and concrete as an engineering material: An historic appraisal and case study analysis. Eng. Fail. Anal. 2014, 40, 114-140. [CrossRef]

15. Mostert, C.; Sameer, H.; Glanz, D.; Bringezu, S. Urban mining for sustainable cities: Environmental assessment of recycled concrete. IOP Conf. Ser. Earth Environ. Sci. 2020, 588, 052021. [CrossRef]

16. Kakkos, E.; Heisel, F.; Hebel, D.E.; Hischier, R. Towards Urban Mining-Estimating the Potential Environmental Benefits by Applying an Alternative Construction Practice. A Case Study from Switzerland. Sustainability 2020, 12, 5041. [CrossRef]

17. Zhang, C.; Hu, M.; Yang, X.; Miranda-Xicotencatl, B.; Sprecher, B.; Di Maio, F.; Zhong, X.; Tukker, A. Upgrading construction and demolition waste management from downcycling to recycling in the Netherlands. J. Clean. Prod. 2020, 266, 121718. [CrossRef]

18. Bertino, G.; Kisser, J.; Zeilinger, J.; Langergraber, G.; Fischer, T.; Österreicher, D. Fundamentals of Building Deconstruction as a Circular Economy Strategy for the Reuse of Construction Materials. Appl. Sci. 2021, 11, 939. [CrossRef]

19. EC. Directive 2008/98/EC of the European Parliament and of the Council of 19 November 2008 on Waste. 2008. Available online: https:/ / eur-lex.europa.eu/legal-content/EN/TXT/PDF/?uri=CELEX:32008L0098\&from=EN (accessed on 21 February 2022).

20. Mostert, C.; Sameer, H.; Glanz, D.; Bringezu, S. Climate and resource footprint assessment and visualization of recycled concrete for circular economy. Resour. Conserv. Recycl. 2021, 174, 105767. [CrossRef]

21. Azúa, G.; González, M.; Arroyo, P.; Kurama, Y. Recycled coarse aggregates from precast plant and building demolitions: Environmental and economic modeling through stochastic simulations. J. Clean. Prod. 2019, 210, 1425-1434. [CrossRef]

22. Zhao, W.; Ren, H.; Rotter, V.S. A system dynamics model for evaluating the alternative of type in construction and demolition waste recycling center-The case of Chongqing, China. Resour. Conserv. Recycl. 2011, 55, 933-944. [CrossRef]

23. Yang, D.; Dang, M.; Sun, L.; Han, F.; Shi, F.; Zhang, H.; Zhang, H. A System Dynamics Model for Urban Residential Building Stock towards Sustainability: The Case of Jinan, China. Int. J. Environ. Res. Public Health 2021, 18, 9520. [CrossRef]

24. EC. Commission Decision of 18 December 2014 Amending Decision 2000/532/EC on the List of Waste Pursuant to Directive. 2014. Available online: https:/ / eur-lex.europa.eu/legal-content/EN/TXT/PDF/?uri=CELEX:32014D0955\&from=EN (accessed on 21 February 2022).

25. Schiller, G.; Deilmann, C.; Reichenbach, J.; Gruhler, K.; Röhm, P.; Baumann, J.; Günther, M. Ermittlung von Ressourcenschonungspotenzialen bei der Verwertung von Bauabfällen und Erarbeitung von Empfehlungen zu deren Nutzung [Determining Resource Conservation Potentials in the Recovery of Construction Waste and Formulating Recommendations on Their Use]. Umweltbundesamt, Texte, 56/2010. 2010. Available online: https://www.umweltbundesamt.de/sites/default/files/medien/ publikation/long/4040.pdf (accessed on 21 February 2022).

26. Azar, A.T. System dynamics as a useful technique for complex systems. Int. J. Ind. Syst. Eng. 2012, 10, 4. [CrossRef]

27. Bossel, H. Modeling and Simulation; A K Peters: New York, NY, USA, 1994. [CrossRef]

28. Maria, A. Introduction to modeling and simulation. In Proceedings of the 29th Conference on Winter Simulation (WSC'97), Atlanta, GA, USA, 7-10 December 1997; pp. 7-13. [CrossRef]

29. Deilmann, C.; Effenberger, K.-H.; Banse, J. Housing stock shrinkage: Vacancy and demolition trends in Germany. Build. Res. Inf. 2009, 37, 660-668. [CrossRef]

30. Destatis. Bautätigkeit und Wohnungen [Construction Activity and Housing]. Fachserie 5, Reihe 1. 2019. Available online: https:/ / www.destatis.de/DE/Themen/Branchen-Unternehmen/Bauen/Publikationen/Downloads-Bautaetigkeit/bautaetigkeit2050100187004.pdf?_blob=publicationFile (accessed on 21 February 2022).

31. Deilmann, C.; Reichenbach, J.; Krauß, N.; Gruhler, K. Materialströme im Hochbau, Potenziale für eine Kreislaufwirtschaft [Material Flows in Building Construction, Potentials for a Circular Economy]. BBSR, Zukunft Bauen: Forschung für die Praxis, 06. 2016. Available online: https:/ / www.bbsr.bund.de/BBSR/DE/veroeffentlichungen/zukunft-bauen-fp/2017/band-06-dl.pdf; jsessionid=690B0CED77266127CA9973CDB565132C.live11294?__blob=publicationFile\&v=1 (accessed on 21 February 2022). 
32. Verian, K.P.; Ashraf, W.; Cao, Y. Properties of recycled concrete aggregate and their influence in new concrete production. Resour. Conserv. Recycl. 2018, 133, 30-49. [CrossRef]

33. DafStb. DAfStb-Richtlinie Beton nach DIN EN 206-1 und DIN 1045-2 mit Rezyklierten Gesteinskörnungen nach DIN EN 12620 [DAfStb-Guideline Concrete According to DIN EN 206-1 and DIN 1045-2 with Recycled Aggregates According to DIN EN 12620]. Deutscher Ausschuss für Stahlbeton e. V. 2019. Available online: http:/ / www.dafstb.de/application/DAfStb-Richtlinie_ Anforderungen_Ausgangsstoffe_Beton_2019-08-15.pdf (accessed on 21 February 2022).

34. Marinković, S.; Radonjanin, V.; Malešev, M.; Ignjatović, I. Comparative environmental assessment of natural and recycled aggregate concrete. Waste Manag. 2010, 30, 2255. [CrossRef]

35. Kazmi, S.M.S.; Munir, M.J.; Wu, Y.-F. Application of waste tire rubber and recycled aggregates in concrete products: A new compression casting approach. Resour. Conserv. Recycl. 2021, 167, 105353. [CrossRef]

36. Fang, X.; Zhan, B.; Poon, C.S. Enhancement of recycled aggregates and concrete by combined treatment of spraying Ca2+ rich wastewater and flow-through carbonation. Constr. Build. Mater. 2021, 277, 122202. [CrossRef]

37. Leibniz Institute of Ecological Urban and Regional Development. Entwicklung der Bautätigkeit [Development of Construction Activity]. 2021. Available online: http:/ /ioer-bdat.de/bauwerksdaten/entwicklung-bautaetigkeit (accessed on 23 February 2022).

38. Bundesanstalt für Geowissenschaften und Rohstoffe. Commodity TopNews 62, Kies-Der Wichtigste Heimische Baustoff! [Gravel-The Most Important Domestic Building Material!]. 2020. Available online: https:/ /www.bgr.bund.de/DE/Gemeinsames/ Produkte/Downloads/Commodity_Top_News/Rohstoffwirtschaft/62_kies.pdf;jsessionid=76D7FAE4BB876227AD2BF87189 DFD678.2_cid321?_blob=publicationFile\&v=5 (accessed on 21 February 2022).

39. Stürmer, S.; Kulle, C. Untersuchung von Mauerwerksabbruch (Verputztes Mauerwerk aus Realen Abbruchgebäuden) und Ableitung von Kriterien für die Anwendung in Betonen mit Rezyklierter Gesteinskörnung (RC-Beton mit Typ 2 Körnung) für den Ressourcenschonenden Hochbau [Investigation of Masonry Demolition (Plastered Masonry from Demolition Buildings) and Derivation of Criteria for the Application in Concretes with Recycled Aggregate (RC Concrete with Type 2 Aggregate) for Resource-Saving Building Construction]. 2017. Available online: https://www.ifeu.de/fileadmin/uploads/2017-10-17 -Abschlussbericht-RC-Beton.pdf (accessed on 21 February 2022).

40. Knappe, F.; Reinhardt, J. Substitution von Primärrohstoffen im Straßen und Wegebau Durch Mineralische Abfälle und Bodenaushub; Stoffströme und Potenziale unter Berücksichtigung von Neu-, Aus- und Rückbau Sowie der Instandsetzung [Substitution of Primary Raw Materials in Road and Path Construction by Mineral Waste and Excavated Soil; Material Flows and Potentials Taking into Account New Construction, Expansion and Deconstruction as Well as Repair]. Umweltbundesamt. 2015. Available online: https:/ / www.bmu.de/fileadmin/Daten_BMU/Pools/Forschungsdatenbank/fkz_3712_33_324_ primaerrohstoffe_strassenbau_bf.pdf (accessed on 21 February 2022).

41. Umweltbundesamt. Deponien Gestern und Heute [Landfills Yesterday and Today]. 2016. Available online: https://www. umweltbundesamt.de/themen/abfall-ressourcen/entsorgung/deponierung-lagerung (accessed on 21 February 2022).

42. Schiller, G.; Gruhler, K.; Ortlepp, R. Quantification of anthropogenic metabolism using spatially differentiated continuous MFA. Chang. Adapt. Soc.-Ecol. Syst. 2017, 3, 119-132. [CrossRef] 